\title{
A global risk assessment model for civil wars ${ }^{\text {is }}$
}

\author{
Nicolas Rost ${ }^{a}$, Gerald Schneider ${ }^{b, *}$, Johannes Kleibl ${ }^{c}$ \\ ${ }^{a}$ United Nations Office for the Coordination of Humanitarian Affairs (OCHA) for Somalia, P.0. Box 28832, 00200 Nairobi, Kenya \\ ${ }^{b}$ Department of Politics and Management, University of Konstanz, Box D86, 78457 Konstanz, Germany

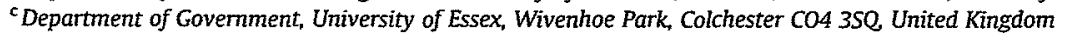

Keywords:

Early warning

Prediction

Civil war

Neural networks

Logit regression

Risk assessment

\begin{abstract}
A B S T R A T
In this study, we construct a multivariate model that assesses the risk of an outbreak of civil war in a country over a period of 5 years into the future. In addition to structural factors of state weakness, which have dominated the literature on civil war onset, this model includes repression of basic human rights to personal integrity - an important harbinger of wars to come - as an aspect of state behavior. Our aim is not to explore the causal factors of civil war onset, but to build a model that includes indicators that correlate with civil war outbreak and may be used to predict it. Based on two versions of the model - logit and neural network - out-of-sample risk assessments for three different time periods are generated and compared to the historical record of civil war outbreak during those years. In addition, the model's ability to produce in-sample risk assessments over a 5-year period is tested. Finally, we compute truly predictive civil war risk assessments for all countries for which data are available, for the years 2008-2012. The analyses show that with a relatively simple model and based on publicly available data sources, meaningful civil war risk assessments can be computed. The quality of the predictions exceeds that of prominent studies, in which the risk of interstate war is assessed.
\end{abstract}

\section{Introduction}

In recent years, much emphasis in academic research and international politics has been put on bringing civil wars to an end, and keeping and building the peace in volatile post-conflict situations. One of the main reasons for post-conflict intervention is the prevention of further violent conflict. At least partly due to an increase in international conflict management efforts to prevent civil wars, their number worldwide has substantially decreased from a peak in the early 1990s (Human Security Centre, 2005, 2006). To allocate scarce resources efficiently, target countries for preventive interventions need to be selected prudently. While potential supporters of a preventive intervention will also take their own interests into account (Bercovitch and Schneider, 2000; Gilligan and Stedman, 2003; Greig, 2005; Greig and Rost, 2005), the main criterion should be the level of risk a country faces for experiencing a civil war in the near future.

In this study, we assess the expected risk countries face to see a civil war erupt within the next 5 years. These risk assessments are generated from multivariate models that are based on theoretical and practical considerations about the factors that correlate with or precede civil war onset. Our aim is thus not further to examine the causes of civil war outbreak in

\footnotetext{
* The views expressed in this paper are those of the authors and do not necessarily reflect those of the United Nations or OCHA. Earlier versions of this study were presented at a convention of the International Relations section of the German Political Science Association, Darmstadt, Germany, 13-14 July 2007: the Annual Conference of the German Peace Psychology Association, Konstanz, Germany, 15-17 June 2007; and the Polarization \& Conflict meeting, Gaillac, France, 7-9 June 2007. We are grateful for the suggestions we have received at these conferences as well as the comments from two anonymous reviewers. We thank Thorsten Meinl for his invaluable help with calculating the neural network models in this study.

* Corresponding author. Fax: +491531882774.

E-mail addresses: rostn@un.org (N. Rost), Gerald.Schneider@uni-konstanz.de (G. Schneider), jkleib@essex.ac.uk (J. Kleibl).
} 
addition to the empirical studies that already explore these causes (e.g., Fearon and Laitin, 2003; Collier and Hoeffler, 2004; Sambanis, 2004; Hegre and Sambanis, 2006). While this study is only a first step towards constructing a comprehensive early warning scheme, practical international conflict management would greatly benefit from such a model, providing policy makers with methodological guidance on how to allocate scarce resources.

After discussing the relevant literature on risk assessment, early warning and civil war, and laying out theoretical expectations about factors that likely are linked to or precede civil war onset, we construct logit and, for comparison, neural network models that take these factors into account. To generate in-sample predictions, we calculate the predicted probability of civil war onset over the next 5 years for each country-year (our unit of analysis). In addition to analyzing the quality of our models with ROC-curves, the highest predicted probabilities are compared to the actual occurrence of war onset. Next, we simulate a situation of genuine risk assessments by restricting the model and data to generate out-of-sample assessments for three test periods (2003-2007, 1998-2002, and 1993-1997). Again, we compare the predicted probabilities to the historical record of civil wars that broke out during each of these 5-year periods and analyze the predictive quality of the models. Finally, we capture the situation as of 2007 (the last year with fully available data) to generate risk assessments for 2008-2012. The current political and security situation in the highest-risk countries is briefly described, as well as observers' perceptions of the risk that these countries slide into violent conflict. In the conclusion, we discuss strengths and limitations of the presented approach with a view to further improve and extend it in the future.

\section{Early warning and risk assessment, civil war and human rights violations}

Early warning and risk assessment models have been constructed and tested for a number of humanitarian catastrophes, using a variety of methods and data types. One can broadly distinguish between models based on qualitative and quantitative data (or those that combine the two), and, among the quantitative models, between those using events-data and those using standards-based data. Along with the methods used, different objectives have been pursued: Whereas qualitative and events-data models, because of the amount of information needed, are usually restricted to one or a few countries or regions, standards-based data models typically operate on a global or at least regional level. While events-data, which may be compiled from news reports on a weekly or even daily basis, allow for temporarily closer early warnings, standards-based data, such as the level of democracy or economic development, are typically available on a yearly basis only. Thus, they allow for longer-term risk assessments. Whereas early warning models aim at pinpointing the occurrence of a certain event in the near future, risk assessment vehicles (as the one in this study) more broadly produce lists of units that face a higherthan-usual risk of experiencing a certain event over a longer period of time. Past forecasting attempts in the social sciences, for both early warning and risk assessment, include models for international conflict (Choucri and Robinson, 1978; Singer and Wallace, 1979; Bueno de Mesquita, 1981; Ward et al., 2007), refugee movements (Gordenker, 1986, 1992), complex humanitarian emergencies (Harff and Gurr, 1998), genocides and politicides (Fein, 1992; Harff, 1998, 2003), ethnic conflict (Gurr and Moore, 1997), state failure (Goldstone et al., 2000, 2005; King and Langche, 2001), general political instability (Bond et al., 1997), civil conflict (Ward and Bakke, 2005), and human rights violations (Poe et al., 2006). ${ }^{1}$ Our risk assessment vehicle builds on quantitative studies of civil war onset, relying on Fearon and Laitin (2003) and Sambanis (2004), two of the most frequently cited articles in this area of research, as a baseline model. One of the central findings of Fearon and Laitin (and other studies such as Hegre et al., 2001; Collier and Hoeffler, 2004, or Sambanis, 2004) is that state weakness increases the probability of a civil war to break out. State weakness can stem from political instability, economic weakness or the reliance on oil as an important source of export revenue. We do not describe the theoretical reasoning behind these factors in detail as our goal is not further to explore the causes of civil war onset. Rather, we build our risk assessment model on these earlier studies, and interested readers should consult them for a description of the causal theories.

Yet, we add some aspects to these models that we expect to strongly correlate with civil war onset but that may not be exogenous causal factors. First, we include a measure of the level of human rights violations. Violations of personal integrity rights may drive people into joining a rebellion (Mason and Krane, 1989; Goodwin, 2001) and contribute to increasing the probability of civil war onset, or constitute a "root cause of conflict" in the words of former UN Secretary General Kofi Annan (2006: 17). But repression is just as likely to be a consequence of a conflict that is already simmering at a level below the civil war-threshold, and civil war has been shown to significantly intensify repression and the risk of genocide (Poe and Tate, 1994; Poe et al., 1999; Rasler, 1986; Zanger, 2000; Krain, 1997; Harff, 2003). In any case, Thoms and Ron (2007) have shown that rights violations and civil war onset are closely correlated, and we believe that the level of repression can be used as a harbinger of civil war.

Second, minor-level conflict is clearly correlated with the outbreak of civil war. Several scholars have argued for a more dynamic understanding of the process that leads to the outbreak of civil war, via the escalation from lower-level conflict (Carey, 2005; Davenport et al., 2006). Rather than causing civil war, minor-level conflict is likely to result from the same underlying causes. Thus, we use it as an indicator of wars to come. Third, we expect military regimes to have a higher probability of experiencing civil wars and use the presence of a military regime as a variable in our model to assess the risk of war. ${ }^{2}$

\footnotetext{
'There are also a number of practical early warning and risk assessment models that are applied in real time such as the Swiss the Swiss Peace Foundation's FAST model, the Conflict Early Warning and Response Mechanism of the Intergovernmental Authority on Development in eastern Africa, or the monthly updates of the International Crisis Group.

2 Note that we do not control for ethnic, religious or linguistic diversity. As Schneider and Wiesehomeier (2008) show, the influence of these social divisions varies a great deal across political systems, making it hard to use them as predictors in a risk assessment exercise like the one we are conducting here.
} 
After this brief description of existing studies on the causes of civil war onset, which we use together with some additional factors to construct a model to produce civil war risk assessments, we now turn to the more practical aspects of building our risk assessment model.

\section{Building a global risk assessment model for civil war}

In this section, we describe a series of steps towards generating global risk assessments for civil war onset, producing forecasts for civil war risk up to the year 2012. Our goal is to explore the possibility of applying social science research to inform practical conflict management. While we do not aim to test causal theory and although there are important differences between theory testing and forecasting, out-of-sample predictions, as several authors have argued, can also be used as a test of theoretical hypotheses (Choucri and Robinson, 1978: 15, Bueno de Mesquita et al., 1985:6; Beck et al,, 2000; Ward et al., 2007). This is especially relevant for true forecasts as the underlying theory cannot be adjusted to empirical observations.

In contrast to several recent risk assessment or early warning models for civil conflict (Goldstone et al., 2000, 2005; Ward and Bakke, 2005), we do not match cases either randomly or based on their similarity on certain variables but use all country-years for which data are available. For practical purposes, we need to construct models that pick out the two or so countries where a civil war breaks out in a given year and not the countries that have experienced state failure before.

From a logit model that we construct based on the theoretical expectations about correlating factors and results from earlier empirical studies outlined above, we compute out-of-sample predictions, compare these to the actual occurrence of civil war, and analyze the predictive quality. Again, we do not describe the theoretical reasoning behind these variables in detail; this information can be found in Fearon and Laitin (2003) and Sambanis (2004), the two studies we use as a baseline.

The dependent variable in the models is civil war onset, coded ' 1 ' for country-years during which a civil war started and ' 0 ' otherwise. We rely on a civil war dataset compiled by Sambanis (2004), which is one of the most comprehensive civil war lists available and which we have updated with the help of the yearly war lists published in the Journal of Peace Research, the Battle Death Data Set (Version 2.0) of the International Peace Research Institute Oslo (PRIO), and PRIO's Armed Conflict Duration Data Version 1-2006b (Gleditsch et al., 2002; Lacina and Gleditsch, 2005; Gates and Strand, 2006). As is standard in empirical studies on civil war onset, ongoing wars are excluded from the analysis.

Independent variables: Similar to the majority of existing research, the level of economic development is proxied by the natural $\log$ of GDP per capita. The data are taken from the Penn World Tables (Heston et al., 2006) and are partially extrapolated with growth data from the World Bank's (2008) World Development Indicators. The dataset of Fearon and Laitin (2003) provides a dummy variable that is coded ' 1 ' if revenues from oil exports account for more than one third of total export revenues and ' 0 ' otherwise, as well as a variable on the percentage of a country's surface that is covered by mountainous terrain. Where data on the percentage of mountainous terrain is not available, they estimate it from the difference between the lowest and the highest geographical point in a country. The mountainous terrain and oil exports data were extrapolated for the period after 1999, as it can be assumed that the values of the mountainous terrain indicator are time-invariant and that those of the oil exports dummy are relatively stable. Fearon and Laitin's dataset is also used as a source for yearly data on population size. The variable is extrapolated with population growth data from the World Development Indicators (World Bank, 2008) and is logged because of its uneven distribution.

Several variables capture aspects of a country's political system. First, the Polity 2 variable from the Polity IV dataset (Marshall and Jaggers, 2007; Gleditsch, 2007) denotes the level of democracy on a 21-point scale reaching from -10 (most authoritarian) to +10 (most democratic). The Polity data measure institutional aspects of a country's democratic system and are thus sufficiently distinct from more behavioral aspects such as state repression. Countries are dichotomously coded as anocracies when their Polity score is between -5 and +5 . Also based on the Polity scale, countries are binarily coded as politically unstable when they have experienced changes of at least three points on the scale in any of the three preceding years, representing major shocks to the political system. Finally, we code countries as governed by a military regime for all country-years in which a country was classified as a military regime according to the data of Hadenius and Teorell (2007), which we updated for 2006 and 2007.

Government repression of rights to personal integrity, which prohibit political imprisonment, torture, 'disappearances,' and unlawful killings, is measured on the five-point Political Terror Scale (PTS), which has been updated by Gibney et al. (2007). A value of ' 1 ' on the scale means that there are no or almost no reported violations, ' 5 ' means that repression is applied indiscriminately against the civilian population. The Political Terror Scale uses two different sources: yearly country reports by Amnesty International and by the US State Department. ${ }^{3}$ For this study, we use the coding based on the Amnesty reports, except for country-years where this information is missing when we revert to the State Department coding to ensure a wider coverage of country-years. The data is available from 1976 onwards, thus limiting the model to the years starting in 1977, as the variable is lagged by one year. Genocides and politicides represent the most egregious form of violations of personal integrity rights. Based on Harff's (2003) list of genocides and politicides, the PTS is modified, re-coding all country-years with a genocide or politicide at the highest possible score of ' 5 .' This allows for the inclusion of genocides and politicides in the data without creating problems of collinearity between the two measures.

\footnotetext{
${ }^{3}$ The Amnesty International country reports are available at www.amnesty.org/ailib/aireport/index.html, the State Department country reports at www.state.gov/g/drl/rls/, accessed November 2005.
} 
Finally, a measure for minor-level violent conflict serves as a harbinger of full-blown civil war. The distinction between civil war and minor-level conflict is based on the reported number of battle deaths. For civil wars, Sambanis (2004: 829-830) uses, among others, the criterion that at least 500-1000 deaths have been directly caused by conflict in one year for that year to be considered as the starting year of a new civil war. For minor-level conflicts, a much lower threshold of at least 25 battle deaths per year but not more than $\mathbf{1 0 0 0}$ over the course of the conflict, is used. Country-years during which minor-level violent conflict was observed are dichotomously coded as ' 1 ' and ' 0 ' otherwise. The data are derived from the UCDP/PRIO Armed Conflict Dataset Version 4-2007 (Gleditsch et al., 2002). With a variable for peace years we control for past exposure to violent conflict. The variable counts the numbers of years that have lapsed since the last armed conflict. ${ }^{4}$.

As a last preparatory step for the multivariate analysis, logged GDP per capita, logged population size, the percentage of mountainous terrain and the peace-years variable are all centered on their mean values, while one point is subtracted from the modified Political Terror Scale, and the anocracy dummy variable is reversed so that ' 1 ' indicates either a democratic or an authoritarian regime and ' 0 ' indicates an anocracy. This facilitates the interpretation of the logit model as the constant now indicates the logarithm of the probability of civil war onset in any given year for a country with an average level of economic development, population size and mountainous terrain, with an anocratic political regime that has been stable for at least three years and is not dominated by the military, where the government does not employ repression, oil exports do not account for at least one third of total exports and no minor-level violent conflict is observed (GDP per capita, population, mountains are at their means. PTS at ' 1 ,' the Polity scale is at ' 0 ' and all dichotomous variables are at ' 0 ').

\section{Empirical results and potentials for real-time risk assessments}

\subsection{In-sample risk assessments}

In a first step, based on Model 1a in Table 1, we produce in-sample risk assessments, compare them to the historical record, and analyze their predictive quality. Some of the results of Model 1a are in line with existing research on the onset of civil war, but there are also some surprisingly diverging findings, as well as some new ones. The risk of civil war onset decreases with a higher level of economic development. This is one of the most robust findings in the civil war literature (Sambanis, 2004; Hegre and Sambanis, 2006), although the relationship has recently been criticized both on theoretical and empirical grounds (Besley and Persson, 2008; Schneider and Wiesehomeier, 2008). In contrast to other studies (e.g. Fearon and Laitin, 2003; Collier et al., 2004), oil exporters are not at a significantly higher risk of conflict in our sample. The level of democracy does not have a statistically significant impact on civil war risk in our model, but anocracies are significantly more dangerous places than both dictatorships and democracies. Military regimes also experience a higher risk of civil war. This factor has not previously been explored in the civil war literature and the finding thus adds to completing the picture of factors associated with a higher risk of civil war onset.

Contrary to Fearon and Laitin's findings (2003), political instability and mountains do not seem to be correlated with internal conflict; both variables are statistically insignificant. The non-result for political instability might be due to two reasons. First, other variables included in this model more closely capture destabilizing factors in the political landscape of a country that can lead to civil war. Military regimes or state repression may contribute more to increasing the probability of civil war onset than changes in the level of democratic development. In fact, this could also push a country to a position where it would be expected to have a lower war risk, e.g. from being an anocracy to a non-anocracy. Second, other aspects of instability such as coups d'état, mass demonstrations or suspensions of parliament might more closely mirror political instability. Unfortunately, comprehensive data on these events are not easily available. Unexpectedly, population size also shows no signs of statistical significance, while this variable was one of the most robust ones in Sambanis (2004) and Hegre and Sambanis (2006). The bivariate relationship between population size and the risk of civil war onset is also not statistically significant. Sambanis (2004) argues that the statistically significant results for the importance of population size in raising the risk of civil war might be a statistical artifact resulting from the high absolute threshold of battle deaths for civil wars. Respect for human rights has a noticeably strong effect: repression significantly increases the probability of civil war onset. This is an interesting and important finding, and has critical policy implications. Rather than quelling claims for political participation, state repression of basic human rights is associated with more discontent. A country's human rights situation is therefore an important factor to include in early warning and risk assessment models for civil war.

For an 'average country', the yearly risk of civil war onset is $0.59 \%$, calculated from the constant of Model $1 \mathrm{a}$ in Table 1 . which represents the logarithm of this probability. An 'average country' thus refers to a country with no or almost no state repression of core human rights, with a Polity 2 score of ' 0 ' (and thus an anocracy), with no political instability, no military regime, no minor internal conflict, no significant oil exports, and average levels of economic development, population size. peace years and mountainous terrain. If this 'average country' were to move up by one point on the Political Terror Scale, the probability would almost double to $1.13 \%$, and would further increase to $7.62 \%$ per year for a country with the highest level of state terror, ceteris paribus. If a fully authoritarian government were to rule this average country (which would thus no

\footnotetext{
${ }^{4}$ We report the descriptive statistics of all variables in a web appendix, available at http://www.uni-konstanz.de/FuF/Verwiss/GSchneider/downloads/ papers/Appendix_riskassessments.pdf.

5 We did not find multi-collinearity to be a problem; there are no pair-wise correlations higher than 0.5 , and most are much lower.
} 
Table 1

Logit regressions of the probability of civil war onset for in-sample risk assessments, 1977-2007.

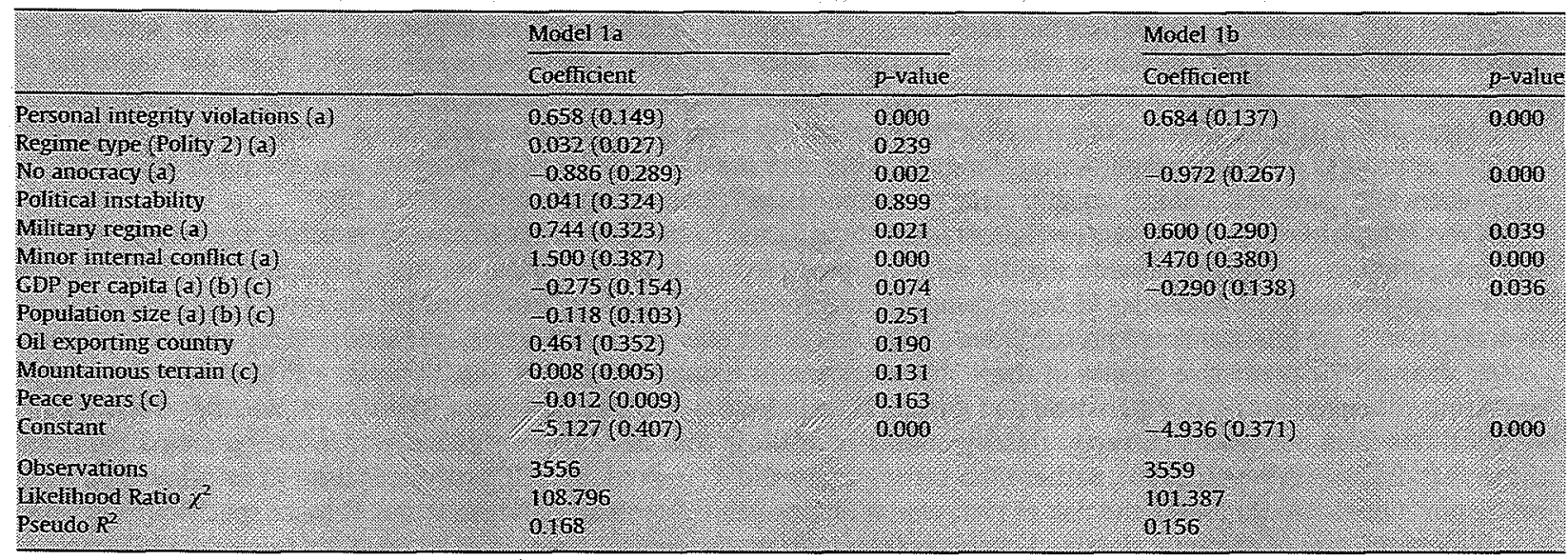

Standard errors in parentheses; $a$, lagged by one year; b. natural log taken; $c$, centered on mean. Variables with a p-value above 0.1 are excluded from Model 1 b.

longer be an anocracy) its yearly probability would drop to $0.18 \%$. Despite the positive coefficient of the regime type variable, a wholly democratic country would have a smaller than average probability of civil war onset at $0.34 \%$, due to the negative impact of the anocracy variable. An otherwise average country with a military regime has an expected civil war probability of $1.23 \%$, more than twice as much than a country with no military regime. Ongoing violent conflict at a level below civil war amplifies the risk to $2.59 \%$, all other variables at average levels.

An increase of one standard deviation in GDP per capita would reduce the civil war risk of the hypothetical average country from $0.59 \%$ to $0.42 \%$. At the maximum level of economic development, with a per capita GDP of $\$ 47,628$ in our sample, the likelihood would further decrease to $0.30 \%$, whereas it would increase to $1.17 \%$ at a minimum per capita GDP of only $\$ 332$. Thus, the level of economic development is an important root cause of domestic war, it alone being associated with an almost four-fold increase in civil war risk from the richest to the poorest country. While this result underlines the importance of long-term development efforts to reduce the risk of war and humanitarian catastrophes, it is not a factor that can be substantially changed in the short-term - in contrast to state repression, which results from a government's behavior rather than structural aspects.

These yearly probabilities are all still relatively low. But of course they do not simply add up for a country that shows several risk factors. Imagine a country with the highest levels of human rights violations, with a semi-developed democratic system but which is still an anocracy (Polity $2=5$ ), which is governed by a military regime and faced with minor-level internal conflict, and which has a minimum level of economic development; in other words, a weak state with a repressive government. Such a country would be faced with a terrifying yearly risk of civil war onset of $64.56 \%$. Now consider a strong state that does not violate physical integrity rights, has a fully authoritarian but not military regime (thus not an anocracy), is not confronted with minor-level conflict, and has a maximum level of economic development. This hypothetical country would have a yearly civil war risk of only $0.09 \%$, according to the model..$^{6}$ These are tremendous differences in the risk level of civil war onset: a weak state with state terror and internal conflict has a probability of a civil war breaking out that is 711 times higher than that of a strong state with no physical integrity violations and minor-level conflict.

Since the goal of this study is to construct a practically functional risk assessment device that minimizes the amount of effort required to gather the necessary data, we test an alternative model without the variables that were found statistically insignificant (at the 10\% level) in Model 1a. Model $1 \mathrm{~b}$ in Table 1 thus excludes the variables for regime type, political instability. population size, oil exports, the percentage of mountainous terrain, and peace years. The results for the remaining variables remain comparable to those of Model 1a; the changes in coefficients and significance levels are minor.

In addition to the logit models, we calculate neural networks - and thus computational information processing models to compare the two approaches. Neural network models, which were developed in engineering, computer science and other disciplines, have been introduced to the conflict literature by Schrodt (2004[1995]). These models generally group cases in a large dataset like the one examined here together in a way analogous to the human brain. In an evaluation of statistical studies of interstate war, Beck et al. (2000) demonstrate the superiority of this artificial intelligence approach over logit models for predictive purposes.

The neural network models used in this study to forecast civil conflict are computed using the 'resilient propagation' (RProp) algorithm by Riedmiller and Braun (1993), which is implemented in the software package KNIME Version 1.3 .5

\footnotetext{
${ }^{6}$ In both of these simulations, there is no political instability, the country is not an important oil exporter, and population size, peace years and the percentage of mountainous terrain are held at their means, as these variables are not statistically significant in Model $1 \mathrm{a}$.
} 
(Berthold et al., 2008). ${ }^{7}$ Like other backpropagation tools, RProp adapts the weights on each connection in the network by propagating the derivatives of the error functions backwards through the network. Technically, backpropagation consists of two steps. First, it computes the impact that each weight has within a network with regard to an (arbitrary) error function. Second, to minimize this error function, it relies on a gradient descent in which the weights are changed in proportion to the selected network learning rate. The RProp algorithm uses, in contrast to other backpropagation solutions, only the sign and not the magnitude of the partial derivative of each error for learning and adaptation. This increases the computational efficiency of the adaptation process and, more importantly, allows learning over the entire network as "weights near the input layer have the equal chance to grow and learn as weights near the output layer" (Riedmiller and Braun, 1993: 588).

As the RProp algorithm starts with weights randomly assigned to the connections between neurons, the results of different computations of a model provide slightly different predicted probabilities. Thus, we run each model ten times and use the average predicted probabilities of these computations for the risk assessments. Based on the results from the logit and neural network models, predicted probabilities of civil war onset over the next 5 years are calculated for each country-year.

We analyze the predictive quality of these risk assessments using ROC-curves. ROC analysis - ROC stands for receiver operating characteristics - is a statistical and graphical technique to analyze classifiers, in our case, whether the predicted probabilities from our model correctly classify countries in those that did experience civil war in the coming 5 years and those that did not (Fawcett, 2006). Rather than setting a threshold (such as .5), ROC analysis is used to calculate how accurately our models would assess the risk of civil war at any possible threshold between 0 and 1 . More specifically, an ROCgraph plots the rate of correctly classified positives (correctly predicted civil wars) over all positives (also called TP-rate, recall or sensitivity) on the $Y$-axis, versus the rate of incorrectly classified negatives (false alarms) over all negatives (also called FP-rate, which is equal to 1 -specificity) on the $X$-axis. Thus, the diagonal $y=x$ represents the accuracy of predictions based on flipping a coin or random guesses; anything under the diagonal would even be worse. In contrast, the further to the top-left corner the ROC-curve is - and thus, the larger the space under the curve - the better the predictive quality (Fawcett, 2006).

The ROC-curves for the in-sample risk assessments from logit models $1 \mathrm{a}$ and $1 \mathrm{~b}$, as well as from the neural network models with the same variables, are shown in Fig. 1 . The performance of the models is relatively constant and decent. The size of the area under the ROC-curve ranges from .78 for both logit models and the first neural network model to 0.81 for the more parsimonious neural network Model $1 \mathrm{~b}$, as this last curve approaches perfect sensitivity much earlier.

We then compared the highest in-sample risk assessments for the country-years 1977-2002 to the historical record: did a civil war erupt in countries with a high predicted probability? Was the risk assessment correct? For logit Model $1 \mathrm{a}$, in 10 out of the 30 highest-risk countries, a war broke out during the 5 following years (among the 30 lowest-risk countries, no war broke out). The more parsimonious logit Model 1 b performed slightly worse, with eight of the 30 highest-risk countries experiencing war. The neural network models performed much better in this regard. For neural network Model 1a, the rate was 25/30 including all of the five top-ranked countries (among the $\mathbf{3 0}$ lowest-risk countries, no war broke out), and for neural network Model 1b 17/30. Over the whole sample included in the analysis, the average probability of civil war onset over a 5 -year period is $6.96 \%$ or about 2 out of 30 countries. ${ }^{8}$ These are of course no real predictions, but merely a preliminary test for the accuracy and usability of the model.

\subsection{Out-of-sample risk assessments}

To simulate a situation of truly predictive risk assessments, we restrict the logit and neural networks model to three time periods, 1977-2002, 1977-1997 and 1977-1992, and generate out-of-sample predictions for the 5-year periods 2003-2007, 1998-2002 and 1993-1997, respectively. We always calculate full and limited models. The logit models are reported in Table 2-1. The substantive results of these models are roughly similar to those of Model 1a. The out-of-sample analyses provide a more 'realistic' picture, simulating a situation where actual forecasts are produced, while still allowing for the possibility to check for the precision of these predictions. The ROC-curves for these 12 models are shown in Fig. 2.

Across the 12 models, the predictive performance of our risk assessment models, as measured by the area under the ROC-curves, ranges from 0.73 for neural network Model $2 \mathrm{c}$ to 0.95 for logit Model 2a. In contrast to the in-sample risk assessments, the logit models perform better than the neural network models in five of the six out-of-sample tests (the exception is Model 2e). One explanation may be that neural network models are fitted to the analyzed data, which becomes more difficult with out-of-sample instead of in-sample tests. Comparing the full models and the more parsimonious models that only include variables with a statistical significance at the $10 \%$ level, the results are mixed. The more parsimonious models (Models $2 \mathrm{~b}, \mathrm{~d}$ and $\mathrm{f}$ ), however, seem to perform a bit better on average: in four of the six cases the area under the ROC-curve is larger here. In addition to the differences between the types of models, there are also clear differences across the three 5-year periods analyzed. The models' performance is best for the 5-year period from 2003 to 2007. based on data as of 2002 , with the area under the ROC-curves above .9 for all four models - an excellent result. The performance of the models is worse for the 5-year period from 1998 to 2002, with the ROC statistics ranging from .73 to 0.78 . The risk assessments perform a bit better again going back another 5 years: For the 1993-1997 risk assessments, the ROC statistics range from 0.77 to 0.81 .

\footnotetext{
${ }^{7}$ For each model, the maximum number of learning iterations was set to 300 , the number of hidden layers to 2 , and the number of hidden neurons per layer to 10 .

${ }^{8}$ The risk of a civil war onset over the next 5 years is calculated as $1-(1-p)^{5}$ whereby $p$ is the predicted probability of civil war onset in a given year.
} 

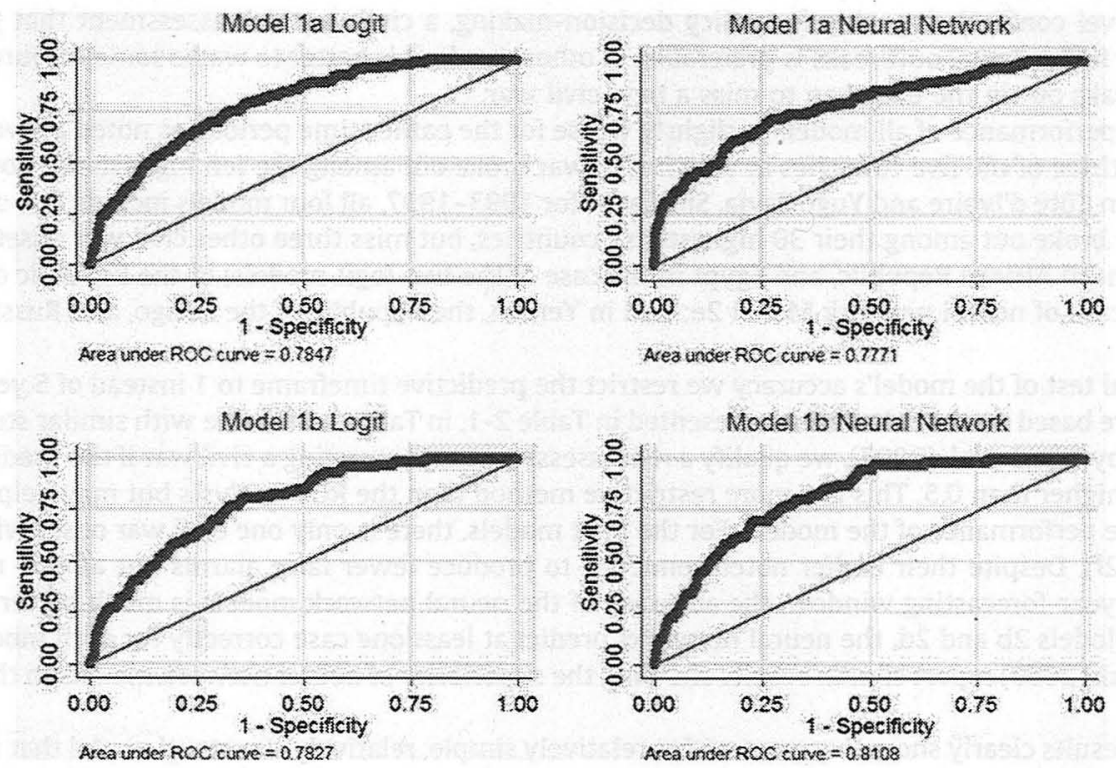

Fig. 1. ROC-curves based on Models $1 \mathrm{a}$ and $1 \mathrm{~b}$.
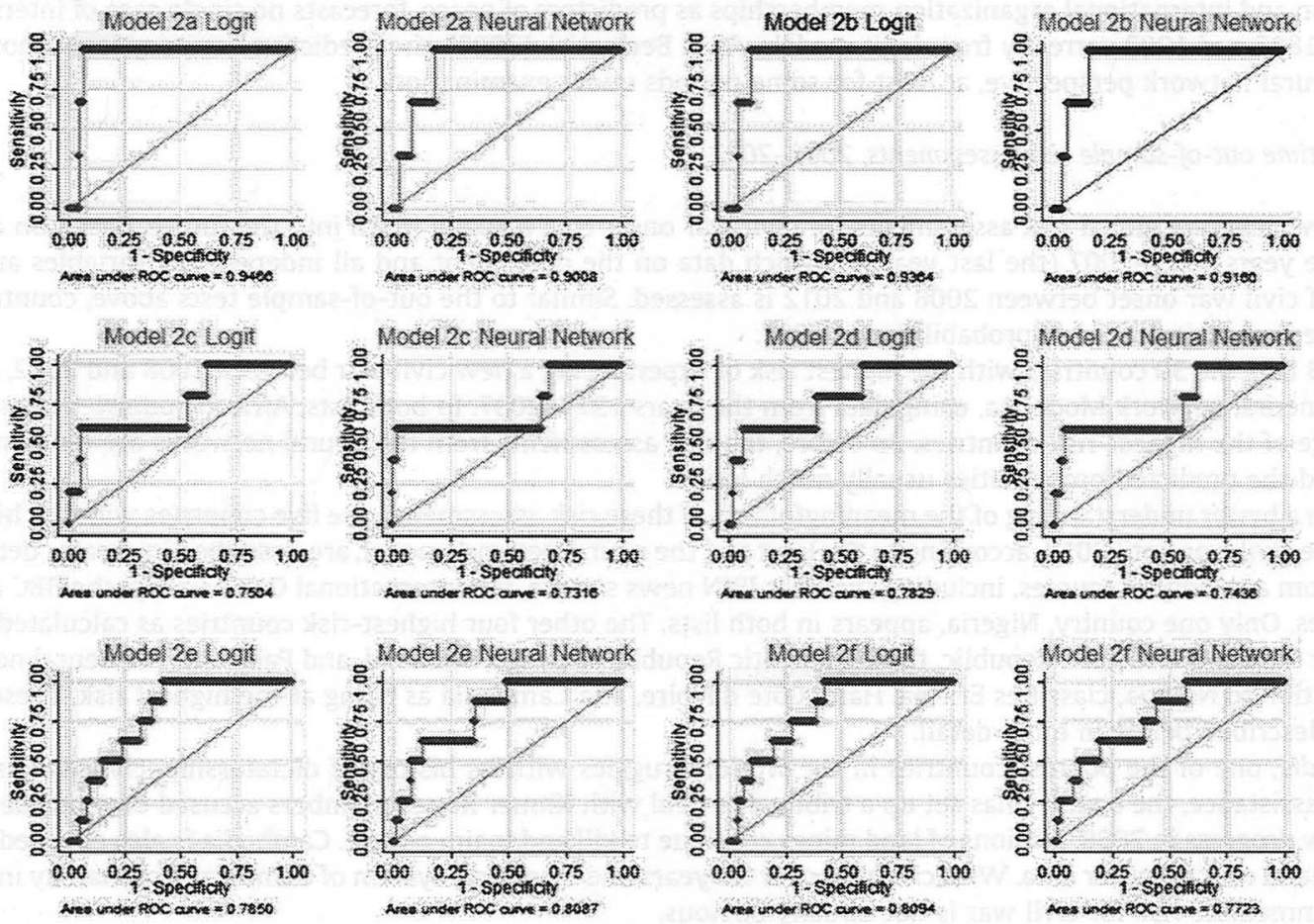

Fig. 2. ROC-curves based on Models $2 \mathrm{a}-2 \mathrm{f}$.

Next, as for the in-sample risk assessments above, we compare the predicted probabilities with the actual occurrence of civil war over the 5-year period examined. In 2003-2007, according to the data sources we use, three civil wars broke out, in Nigeria, Somalia, and Iraq. All four models rank these three countries as among those 30 countries with the highest risk in 2002 , although the neural network models rank them lower, on average, than the logit models. For instance, logit Model $2 \mathrm{a}$ assigns Iraq a predicted probability of $27 \%$ to experience civil war onset in 2002-2007 and ranks it as the 12 th highest-riskcountry. The corresponding neural network model predicts a probability of $2 \%$ and gives Iraq rank 27 . Overall the neural network models issue more conservative risk assessments, while the logit models assign high priorities to some countries that then do not experience civil war, such as the Central African Republic with a predicted probability of $96 \%$ for 2003-2007 
(there was low-level conflict). Arguably for policy decision-making, a civil war risk assessment that produces some false alarms but misses fewer actual outbreaks is preferable. In other words, it is better to waste some resources on a risk-country where no war breaks out in the end than to miss a new civil war.

The predictive performance of all models is slightly worse for the earlier time periods as noted above. For 1998-2002, all four models rank three of the five countries in which civil war broke out among the ten highest-risk countries, but miss the two other onsets in Côte d'Ivoire and Yugoslavia. Similarly, for 1993-1997, all four models include five of the eight countries in which civil war broke out among their 30 highest-risk countries, but miss three other civil war onsets: in the Republic of the Congo, the Central African Republic, and Egypt in the case of the two logit models; in the Republic of the Congo, Yemen, and Nepal in the case of neural network Model 2e; and in Yemen, the Republic of the Congo, and Russia in neural network Model 2f.

As an additional test of the model's accuracy we restrict the predictive timeframe to 1 instead of 5 years. We report these analyses, which are based on the calculations presented in Table 2-1, in Table 2-2. In line with similar studies such as a study on interstate war by Ward et al. (2007), we qualify a risk assessment as forecasting a civil war if the predicted probability of a civil war onset is higher than 0.5 . This is a more restrictive method than the ROC analysis but may help to give a more concrete picture of the performance of the models. For the logit models, there is only one civil war onset which is correctly predicted (in Model $2 \mathrm{f}$ ). Despite their earlier noted tendency to produce fewer false alarms but also to miss many civil war onsets within a 5 year-forecasting window, the accuracy of the neural network models is much better in these tests. With the exception of Models $2 \mathrm{~b}$ and $2 \mathrm{~d}$, the neural networks predict at least one case correctly for each model, and up to five in Model 2f. Beck et al. (2000) report similar results showing the superiority of neural network models in this kind of predictive exercises.

Overall, these results clearly show that even with a relatively simple, relatively structural model that uses only standardsbased and publicly available data, meaningful, forward-looking risk assessments can be produced. Furthermore, the theoretical models that we used to generate the predictions work better than the models that are used to explain and forecast interstate war. According to Ward et al. (2007), the so-called Kantian theory of peace, which focuses on democracy, economic integration and international organization memberships as predictors of peace, forecasts no single case of interstate conflict between 1885 and 1992 correctly from logit models. As in Beck et al. (2000), the predictive accuracy looks more promising from a neural network perspective, at least for some periods under examination.

\subsection{Real-time out-of-sample risk assessments, 2008-2012}

We now generate global risk assessments for civil war onset that actually reach into the future. Based on a model that covers the years 1977-2007 (the last year for which data on the dependent and all independent variables are available), the risk of civil war onset between 2008 and 2012 is assessed. Similar to the out-of-sample tests above, countries are classified based on their predicted probabilities in 2007.

Table 3 lists the 30 countries with the highest risk of experiencing a new civil war between 2008 and 2012, according to logit and neural network Model 1a, using data from the years 1977-2007. In both lists, African countries constitute a high percentage of the highest-risk countries. As before, the risk assessments from the neural networks are much more conservative, and the predicted probabilities usually much lower.

To gain a better understanding of the meaningfulness of these risk assessments, the five countries with the highest risk to experience civil war until 2012, according to the logit and the neural network model, are described in greater detail, based on reports from a variety of sources, including the UN's IRIN news service, the International Crisis Group, the BBC and the New York Times. Only one country, Nigeria, appears in both lists. The other four highest-risk countries as calculated by the logit model are the Central African Republic, the Democratic Republic of Congo, Thailand, and Pakistan. The neural network model, in addition to Nigeria, classifies Eritrea, Haiti, Côte d'Ivoire, and Cambodia as being at the highest risk. These nine countries are described below in more detail.

Cambodia, one of the poorest countries in the world, struggles with its history of dictatorship, civil war and genocide. With UN assistance, the country has set up a tribunal to deal with Khmer Rouge members accused of genocide, which only made slow progress in 2008. Millions of land mines continue to kill and maim people. Cambodia is also engaged in a dispute with Thailand over a border area. With civil war over for years and a political system of democratic monarchy in place, however, an immediate risk for civil war is not directly obvious.

A low-level political conflict has been ongoing in the Central African Republic since 2005 when several groups took up arms against President Bozizé who had won elections 2 years after taking power in a coup. In addition, brutal bandits have taken advantage of the state's absence in many areas outside the capital Bangui and attack travelers or whole villages. A 'political dialogue' between the government and rebel groups took place in December 2008 but new groups have emerged since and low-level conflict continues across the north of the country. The situation in the Central African Republic also highly depends on developments in neighboring Democratic Republic of the Congo, Darfur and Chad. The Central African Republic is thus clearly at high risk for civil war onset.

The situation in Côte d'Ivoire, after long years of civil war is still unstable. Côte d'Ivoire still remains split between the north held by the opposition New Forces and the south where President Gbagbo resides in the capital Abidjan. Observers warn that the country could slip back into civil war. The International Crisis Group (2006), for example, alerts that the "real civil war may yet be still to come." Côte d'Ivoire is thus clearly a candidate for the highest warning level for civil war. 
Table 2-1

Logit regressions of the probability of civil war onset for out-of-sample risk assessments.

\begin{tabular}{|c|c|c|c|c|c|c|c|c|c|c|c|c|}
\hline & \multicolumn{4}{|l|}{$1977-2002$} & \multicolumn{4}{|l|}{$1977-1997$} & \multicolumn{4}{|l|}{$1977-1992$} \\
\hline & \multicolumn{2}{|l|}{ Model 2a } & \multicolumn{2}{|l|}{ Model $2 \mathrm{~b}$} & \multicolumn{2}{|l|}{ Model 2c } & \multicolumn{2}{|l|}{ Model 2d } & \multicolumn{2}{|l|}{ Model 2e } & \multicolumn{2}{|l|}{ Model $2 \mathrm{f}$} \\
\hline & Coef. & p-value & Coef. & $p$-value & Coef. & $p$-value & Coef. & $p$-value & Coef: & $p$-value & Coef. & $p$-value \\
\hline Personal integrity violations (a) & $0.700(0.151)$ & 0.000 & $0.742(0.141)$ & 0.000 & $0.707(0.162)$ & 0.000 & $0.746(0.151)$ & 0.000 & $0.892(0.182)$ & 0.000 & $\begin{array}{l}0.835 \\
(0.171)\end{array}$ & 0.000 \\
\hline Regime type (Polity 2) (a) & $0.055(0.029)$ & 0.056 & $0.041(0.027)$ & 0.131 & $0.064(0.031)$ & 0.038 & $0.045(0.029)$ & 0.115 & $0.086(0.035)$ & 0.014 & $\begin{array}{l}0.072 \\
(0.033)\end{array}$ & 0.031 \\
\hline No anocracy (a) & $-1.054(0.307)$ & 0.001 & $-1.037(0.280)$ & 0.000 & $-1.256(0.333)$ & 0.000 & $-1.175(0.298)$ & 0.000 & $-1.286(0.393)$ & 0.001 & $\begin{array}{r}-1.150 \\
(0.355)\end{array}$ & 0.001 \\
\hline Political instability & $-0.116(0.343)$ & 0.736 & & & $-0.263(0.382)$ & 0.491 & & & $-0.512(0.468)$ & 0.273 & & \\
\hline Military regime (a) & $0.938(0.339)$ & 0.006 & $0.864(0.328)$ & 0.008 & $0.804(0.352)$ & 0.022 & $0.697(0.340)$ & 0.040 & $0.656(0.392)$ & 0.094 & $\begin{array}{l}0.514 \\
(0.379)\end{array}$ & 0.175 \\
\hline Minor internal conflict (a) & $1.693(0.397)$ & 0.000 & $1.604(0.387)$ & 0.000 & $1.821(0.432)$ & 0.000 & $1.646(0.416)$ & 0.000 & $\begin{array}{l}1.455 \\
(0.533)\end{array}$ & 0.006 & $\begin{array}{l}1.332 \\
(0.514)\end{array}$ & 0.010 \\
\hline GDP per capita (a) (b) (c) & $-0.349(0.162)$ & 0.032 & $-0.356(0.147)$ & 0.015 & $-0.466(0.181)$ & 0.010 & $-0.445(0.158)$ & 0.005 & $\begin{array}{l}-0.457 \\
(0.213)\end{array}$ & 0.032 & $\begin{array}{l}-0.408 \\
(0.200)\end{array}$ & 0.041 \\
\hline Population size (a) (b) (c) & $-0.129(0.106)$ & 0.226 & & & $-0.135(0.113)$ & 0.234 & & & $-0.183(0.123)$ & 0.135 & & \\
\hline Oil exporting country & $0.520(0.369)$ & 0.158 & & & $0.594(0.388)$ & 0.126 & & & $0.140(0.491)$ & 0.776 & & \\
\hline Mountainous terrain (c) & $0.008(0.006)$ & 0.168 & & & $0.008(0.006)$ & 0.155 & & & $0.007(0.007)$ & 0.340 & & \\
\hline Peace years (c) & $-0.012(0.009)$ & 0.207 & & & $-0.011(0.010)$ & 0.292 & & & $-0.025(0.013)$ & 0.045 & $\begin{array}{l}-0.027 \\
(0.012)\end{array}$ & 0.026 \\
\hline Constant & $-4.986(0.422)$ & 0.000 & $-4.919(0.396)$ & 0.000 & $-4.672(0.450)$ & 0.000 & $-4.638(0.423)$ & 0.000 & $-4.679(0.525)$ & 0.000 & $\begin{array}{r}-4.665 \\
(0.491)\end{array}$ & 0.000 \\
\hline Observations & 2878 & & 2880 & & 2218 & & 2220 & & 1621 & & 1623 & \\
\hline $\begin{array}{l}\text { Likelihood Ratio } \chi^{2} \\
\text { Pseudo } R^{2}\end{array}$ & $\begin{array}{l}109.715 \\
0.186\end{array}$ & & $\begin{array}{l}103.196 \\
0.175\end{array}$ & & $\begin{array}{l}102.023 \\
0.201\end{array}$ & & $\begin{array}{l}95.251 \\
0.187\end{array}$ & & $\begin{array}{l}86.420 \\
0.218\end{array}$ & & $\begin{array}{l}82.206 \\
0.207\end{array}$ & \\
\hline
\end{tabular}

Standard errors in parentheses; $a$, lagged by one year; $b$, natural log taken; $c$, centered on mean. Variables with a $p$-value above 0.1 are excluded from Models $2 b$, $2 d$ and $2 f$. 
Table 2-2

Out-of-sample predictions of civil war onset.

\begin{tabular}{|c|c|c|c|c|c|c|c|}
\hline \multicolumn{2}{|c|}{ Predicted probability of civil war onset } & No onset & Civil war onset & Total & No onset & Civil war onset & Total \\
\hline & & \multicolumn{3}{|c|}{ Model 2a (2003-007) } & \multicolumn{3}{|c|}{ Model 2b (2003-007) } \\
\hline Logit & $\begin{array}{l}p<0.5 \\
p \geq 0.5\end{array}$ & $\begin{array}{l}673 \\
99.85 \% \\
1 \\
0.15 \%\end{array}$ & $\begin{array}{l}4 \\
100.00 \% \\
0 \\
0.00 \%\end{array}$ & $\begin{array}{l}677 \\
99.85 \% \\
1 \\
0.15 \%\end{array}$ & $\begin{array}{l}674 \\
99.85 \% \\
1 \\
0.15 \%\end{array}$ & $\begin{array}{l}4 \\
100.00 \% \\
0 \\
0.00 \%\end{array}$ & $\begin{array}{l}678 \\
99.85 \% \\
1 \\
0.15 \%\end{array}$ \\
\hline \multirow[t]{2}{*}{ Neural Network } & $\begin{array}{l}p<0.5 \\
p \geq 0.5 \\
\text { Total }\end{array}$ & $\begin{array}{l}669 \\
99.26 \% \\
5 \\
0.74 \% \\
674\end{array}$ & $\begin{array}{l}3 \\
75.00 \% \\
1 \\
25.00 \% \\
4\end{array}$ & $\begin{array}{l}672 \\
99.12 \% \\
6 \\
0.88 \% \\
678\end{array}$ & $\begin{array}{l}674 \\
99.85 \% \\
1 \\
0.15 \% \\
675\end{array}$ & $\begin{array}{l}4 \\
100.00 \% \\
0 \\
0.00 \% \\
4\end{array}$ & $\begin{array}{l}678 \\
99.85 \% \\
1 \\
0.15 \% \\
679\end{array}$ \\
\hline & & \multicolumn{3}{|c|}{ Model $2 c(1998-2007)$} & \multicolumn{3}{|c|}{ Model 2d (1998-2007) } \\
\hline Logit & $\begin{array}{l}p<0.5 \\
p \geqslant 0.5\end{array}$ & $\begin{array}{l}1.320 \\
99.47 \% \\
7 \\
0.53 \%\end{array}$ & $\begin{array}{l}11 \\
100.00 \% \\
0 \\
0.00 \%\end{array}$ & $\begin{array}{l}1,331 \\
99.48 \% \\
7 \\
0.52 \%\end{array}$ & $\begin{array}{l}1.318 \\
99.25 \% \\
10 \\
0.75 \%\end{array}$ & $\begin{array}{l}11 \\
100.00 \% \\
0 \\
0.00 \%\end{array}$ & $\begin{array}{l}1,329 \\
99.25 \% \\
10 \\
0.75 \%\end{array}$ \\
\hline \multirow[t]{2}{*}{ Neural Network } & $\begin{array}{l}p<0.5 \\
p \geqslant 0.5 \\
\text { Total }\end{array}$ & $\begin{array}{l}1308 \\
98.57 \% \\
19 \\
1.43 \% \\
1327\end{array}$ & $\begin{array}{l}10 \\
90.91 \% \\
1 \\
9.09 \% \\
11\end{array}$ & $\begin{array}{l}1318 \\
98.51 \% \\
20 \\
1.49 \% \\
1338\end{array}$ & $\begin{array}{l}1320 \\
99.40 \% \\
8 \\
0.60 \% \\
1328\end{array}$ & $\begin{array}{l}11 \\
100.00 \% \\
0 \\
0.00 \% \\
11\end{array}$ & $\begin{array}{l}1331 \\
99.40 \% \\
8 \\
0.60 \% \\
1339\end{array}$ \\
\hline & & \multicolumn{3}{|c|}{ Model 2e (1993-2007) } & \multicolumn{3}{|c|}{ Model 2f (1993-2007) } \\
\hline Logit & $\begin{array}{l}p<0.5 \\
p \geq 0.5\end{array}$ & $\begin{array}{l}1894 \\
99.01 \% \\
19 \\
0.99 \%\end{array}$ & $\begin{array}{l}22 \\
100.00 \% \\
0 \\
0.00 \%\end{array}$ & $\begin{array}{l}1916 \\
99.02 \% \\
19 \\
0.98 \%\end{array}$ & $\begin{array}{l}1893 \\
98.90 \% \\
21 \\
1.10 \%\end{array}$ & $\begin{array}{l}21 \\
95.45 \% \\
1 \\
4.55 \%\end{array}$ & $\begin{array}{l}1914 \\
98.86 \% \\
22 \\
1.14 \%\end{array}$ \\
\hline Neural Network & $\begin{array}{l}p<0.5 \\
P \geq 0.5 \\
\text { Total }\end{array}$ & $\begin{array}{l}1817 \\
94.98 \% \\
96 \\
5.02 \% \\
1913\end{array}$ & $\begin{array}{l}18 \\
81.82 \% \\
4 \\
18.18 \% \\
22\end{array}$ & $\begin{array}{l}1835 \\
94.83 \% \\
100 \\
5.17 \% \\
1935\end{array}$ & $\begin{array}{l}1838 \\
96.03 \\
76 \\
3.97 \% \\
1914\end{array}$ & $\begin{array}{l}17 \\
77.27 \% \\
5 \\
22.73 \% \\
22\end{array}$ & $\begin{array}{l}1855 \\
95.82 \% \\
81 \\
4.18 \% \\
1936\end{array}$ \\
\hline
\end{tabular}

The situation in the Democratic Republic of the Congo, though much more complex, is not that different from the Central African Republic as described above: A president who won elections after taking power by force, ongoing violent conflict with rebel groups, and brutal bandits capitalizing on the weakness and absence of the state. Even after the most deadly (internationalized civil) war since the Second World War officially ended in 2003, people in the Democratic Republic of the Congo have been facing one of the world's worst humanitarian crises. General Laurent Nkunda's CNDP rebel group resumed fighting in November 2006 until he was arrested in Rwanda. In June 2008, the FDLR rebel group attacked civilians in eastern Congo. Hundreds of thousands of civilians have been displaced. The political situation remains unsteady. In March 2008, about 100 civilians died in brutal police crackdowns. While President Kabila's main contender Jean-Pierre Bemba was arrested in 2008 following an indictment by the International Criminal Court, many contest Kabila's increasingly authoritarian rule and renewed civil war cannot be ruled out.

In Eritrea, the risk of war seems to stem more from a renewed armed conflict with Ethiopia over an unresolved border dispute, rather than from a civil war. The situation has remained tense since a border war in 1998-2000, with observers saying that the two countries have been fighting a proxy war in neighboring Somalia. Eritrea also has a non-demarcated border with Sudan, and has engaged in military conflicts with Yemen in 1996 and Djibouti in 2008. In addition, there is also some potential for domestic conflict in Eritrea: It is one of poorest countries in the world, many of its people rely on food aid, human rights are often violated, and military spending is hindering economic progress.

Haiti is the poorest country in the western hemisphere. After years of political violence, brutal repression, and military coups, Haiti has been governed by an elected government since June 2006. However, armed groups clash regularly and criminals kidnap civilians for ransom. According to the UN, the human rights situation remains 'catastrophic'. Riots over increased food prices in April 2008 underlined the volatility of the situation in Haiti.

Despite turning towards democracy (although the most recent elections were heavily criticized), Nigeria has been shaken by ethnic and religious conflicts and conflicts over the use of oil. Since 1999, at least 14,000 people have died, mostly in communal strife. Power is centralized and corruption is rampant. Despite its oil wealth, $92.4 \%$ of the population live on less than two dollars a day (UNDP, 2008). At the same time, armed groups are proliferating, particularly in the oil-rich Niger Delta. All these factors indicate a high risk of a new civil war breaking out, which would have repercussions in the entire region.

Taliban fighters are increasingly relying on areas in Pakistan as a haven for staging attacks, both here and in Afghanistan. Taliban troops regularly engage government forces in fights, a situation that could escalate to a full-blown civil war, which 
Table 3

Out-of-sample risk assessments for 30 highest-risk countries, 2008-2012, based on Model 1a.

\begin{tabular}{|c|c|c|c|c|c|}
\hline \multicolumn{6}{|c|}{ Predicted probabilities of civil war onset for $2008-2012$} \\
\hline \multicolumn{3}{|c|}{ Logit } & \multicolumn{3}{|c|}{ Neural Network } \\
\hline 1 & Central African Republic & 0.937 & 1 & Eritrea & 0.280 \\
\hline 2 & Dem. Rep. of the Congo & 0.797 & 2 & Haiti & 0.215 \\
\hline 3 & Thailand & 0.637 & 3 & Nigeria & 0.128 \\
\hline 4 & Pakistan & 0.367 & 4 & Côte d'voire & 0.125 \\
\hline 5 & Nigeria & 0.360 & 5 & Cambodia & 0.079 \\
\hline 6 & Burundi & 0.319 & 6 & Yemen & 0.078 \\
\hline 7 & Haiti & 0.318 & 7 & Sierra Leone & 0.075 \\
\hline 8 & Eritrea & 0.261 & 8 & Djibouti & 0.051 \\
\hline 9 & Côte d'lvoire & 0.256 & 9 & Zambia & 0.050 \\
\hline 10 & Rwanda & 0.255 & 10 & Kenya & 0.041 \\
\hline 11 & Nepal & 0.243 & 11 & Angola & 0.040 \\
\hline 12 & Yemen & 0.241 & 12 & Venezuela & 0.039 \\
\hline 13 & Rep. of the Congo & 0.238 & 13 & Guatemala & 0.038 \\
\hline 14 & Tajikistan & 0.221 & 14 & Lesotho & 0.036 \\
\hline 15 & Ethiopia & 0.213 & 15 & Central African Republic & 0.029 \\
\hline 16 & Togo & 0.208 & 16 & Honduras & 0.025 \\
\hline 17 & Kyrgyzstan & 0.198 & 17 & Papua New Guinea & 0.025 \\
\hline 18 & Mauritania & 0.189 & 18 & Rep. of the Congo & 0.023 \\
\hline 19 & Angola & 0.187 & 19 & Syria & 0.022 \\
\hline 20 & Cambodia & 0.168 & 20 & Mongolia & 0.021 \\
\hline 21 & Djibouti & 0.152 & 21 & Liberia & 0.020 \\
\hline 22 & Egypt & 0.150 & 22 & Burkina Faso & 0.020 \\
\hline 23 & Guatemala & 0.150 & 23 & Gambia & 0.019 \\
\hline 24 & Turkey & 0.139 & 24 & Peru & 0.019 \\
\hline 25 & Liberia & 0.135 & 25 & Egypt & 0.019 \\
\hline 26 & Guinea Bissau & 0.127 & 26 & Rwanda & 0.018 \\
\hline 27 & Zambia & 0.124 & 27 & Tanzania & 0.017 \\
\hline 28 & Syria & 0.119 & 28 & Dem. Rep. of the Congo & 0.015 \\
\hline 29 & Sierra Leone & 0.119 & 29 & Burundi & 0.015 \\
\hline 30 & Gambia & 0.118 & 30 & Turkey & 0.014 \\
\hline
\end{tabular}

would have devastating consequences for the whole region. Fighting between the government and the Taliban in the Swat valley in April, May and June 2009 can probably already be classified as a new civil war, given (yet to be verified) reports on high numbers of casualties on both sides. An escalation of the tense political situation or further assassinations of politicians, following the killing of Benazir Bhutto in December 2007, could also trigger more violence. Lahore journalist Ahmed Rashid describes the situation in the region as a 'descent into chaos' (2008).

Despite recent political unrest, Thailand was the most surprising country on this list. Its economy is much more advanced and its people on average richer than in the other 'very high risk' countries. Still, several risk factors are clearly present. In 2004 , separatists in the south took up arms against the government and about 3000 people have been killed in clashes. Human rights violations are rampant. In September 2006, a military regime took over the government.

In sum, all these nine countries are characterized by a history of violence, coups d'état, authoritarian government, human rights violations, and state failure. With the exception of authoritarian Eritrea, all of these countries are anocracies - unstable political regimes 'in the middle'. In several countries, including the Democratic Republic of the Congo and Nigeria, natural resources have fueled violence. Though only one, Nigeria, is an oil exporter, corruption is common in most of them. UN peacekeeping or peace-building missions are active in three of the nine countries, Haiti, the Central African Republic and the Democratic Republic of the Congo. With the possible exceptions of Thailand and Cambodia, we are confident that these countries do face a particularly high risk of civil war over the coming years.

\section{Conclusion}

There are today a number of early warning and risk assessment models, to warn of various potential humanitarian catastrophes, including drought, tsunamis and political instability. Yet, Kofi Annan, a former UN Secretary General, in a report on conflict prevention, found that the UN had made "no significant progress" in strengthening capacities for early warning, information collection and analysis and that it lacked the "capability to analyze and integrate data from different parts of the system into comprehensive early warning reports and strategies on conflict prevention" (Annan, 2006:27). We conclude that with standards-based, yearly data that are publicly available it is possible to construct a model that generates meaningful and practically applicable global risk assessments for civil war onset. Our models identify nine countries that are at a very high risk of a new civil war until 2012. Policy decisions on the allocation of resources for conflict prevention should never be solely based on a statistical risk assessment model. Rather, the countries included in this risk-list should receive increased attention and close monitoring from political observers. Ideally, relatively structural risk assessment models are combined 
with early warning devices that by using events-data put more emphasis on daily events. Models based on quantitative data should be combined with qualitative observations. Global monitoring should be combined with the knowledge of country experts. Most importantly, countries that are excluded from this model because of a lack of available data must not be overlooked, as lack of data itself can be an indicator of political instability and conflict. ${ }^{9}$ Nonetheless, risk assessments such as the one presented in this study have the potential to contribute to a more efficient resource allocation in attempts to prevent deadly conflict and human suffering. The development of functional early warning and risk assessment vehicles might also contribute to closing the still-existing gap between early warning and early response. In fact, we hope that risk assessments such as this, combined with in-depth country analyses, will help policymakers to prevent civil wars from breaking out in high-risk countries - so that we will never know whether our analyses were right.

As a first step to improve the usability of risk assessment models, the problem of missing data, especially in high-risk countries, has to be addressed. Other avenues of possible future research and applicability include the development of a model that more closely examines the dynamics that lead from political contentions via low-intensity conflict to full-scale civil war. The use of events-data, and the combination of standards-based and events-data in one model might help to achieve this goal. A better understanding of the process of conflict escalation and the role that government behavior is playing in this process, or a comprehensive theory of how different forms of violence (civil war, genocide, politicide, human rights violations, international conflict, coups d'état, etc.) interact could be applied to constructing early warning and risk assessment models for a variety of human-made humanitarian disasters. Early warning and conflict risk assessment are still in their early stages.

\section{References}

Annan, K., 2006. Progress Report on the Prevention of Armed Conflict. Available from: <Www.reliefweb.int/rw/Lib.nsf/db900SID/HVAN-6SXRAN? OpenDocument> (accessed September 2006).

Beck, N., King, G., Langche, Z., 2000. Improving quantitative studies of international conflict: a conjecture. American Political Science Review $94,21-35$.

Bercovitch, J Schneider, G., 2000. Who mediates? The political economy of international conflict management Journal of Peace Research 37, 145-165.

Berthold, M.R., Cebron, N., Dill, F., Gabriel, T.R., Kötter. T., Meinl, T., Ohl, P.. Sieb. Ch.. Thiel, K., Wiswedel, B., 2008. KNIME: the Konstanz information miner.

In: Preisach, Ch., Burkhardt, H., Schmidt-Thieme, L, Decker, R. (Eds.), Data Analysis, Machine Learning and Applications. Springer, Berlin, pp. 319-326.

Besley. T., Persson, T., 2008. Wars and state capacity. Journal of the European Economic Association 6, 522-530.

Bond, D.J., Craig. J., Taylor, Ch.L., Schock, K., 1997. Mapping mass political conflict and civil society: issues and prospects for the automated development of event data. Journal of Conflict Resolution 41, 553-579.

Bueno de Mesquita, B., 1981. The War Trap. Yale University Press, New Haven.

Bueno de Mesquita, B., Newman. D., Rabushka, A., 1985. Forecasting Political Events - The Future of Hong Kong. Yale University Press, New Haven.

Carey, S.C., 2005. Patterns of authority and the escalation of intrastate conflict. Paper Presented at the ECPR General Conference in Budapest, 8-10 September 2005

Choucri, N., Robinson, T.S., 1978. Forecasting in International Relations - Theory, Methods, Problems, Prospects. Freeman, San Francisco.

Collier, P.. Hoeffler. A., 2004. Greed and Grievance in Civil War. Oxford Economic Papers.

Collier, P., Hoeffler, A., Söderbom, M.; 2004. On the duration of civil war. Journal of Peace Research 41, $253-273$.

Davenport, Ch., Armstrong. D.A., Lichbach, M.I., 2006. Conflict escalation and the origins of civil war. Working Paper. Available from: <www.bsos.umd.edu/ gvpt/davenport/dcawcp/paper/111605.pdf $>$ (accessed August 2006).

Fawcett, T., 2006. An introduction to ROC analysis. Pattern Recognition Letters 27, 861-874.

Fearon, J.D., Laitin, D.D., 2003. Ethnicity, insurgency, and civil war. American Political Science Review 75, 90.

Fein. H., 1992. Dangerous states and endangered people: implications of life integrity violations analysis. In: Rupesinghe, K., Kuroda, M. (Eds.), Early Warning and Conflict Resolution. St. Martin's, New York, pp. 30-40.

Gates, S., Strand. H., 2006. Modeling the duration of civil wars: measurement and estimation issues. Working Paper.

Gibney. M. Comett, L., Wood, R., 2007. Political Terror Scale 1976-2006. Available from: <www.politicalterrorscale.org> (accessed July 2008).

Gilligan, M., Stedman, S., 2003. Where do peacekeepers go? International Studies Review 5, 37-54.

Gleditsch, K.S., 2007. Modified Polity P4 and P4D Data, Version 2.0. Available from: <http://privatewww.essex.ac.uk/ksg/Polity.html> (accessed July 2008)

Gleditsch, N.P., Wallensteen, P., Eriksson, M., Sollenberg, M., Strand, H., 2002. Armed conflict 1946-2001: a new dataset. Journal of Peace Research 39, 615637.

Goldstone, J.A., Gurr, T.G., Harf, B., Levy, M.A., Marshall, M.G., Bates, R.H., Epstein, D.L. Kahl, C.H., Surko, P.T., Ulfelder, J.C., Unger, A.N., 2000. State Failure Task Force Project: Phase III Findings. Available from: <www.cidcm.umd.edu/inscr/stfail/SFTF\%20Phase\%20ll\%20Report\%20Final.pdf> (accessed November 2003).

Goldstone, J.A., Bates, R.H., Gurr, T.R., Lustik, M., Marshall, M.G., Ulfelder, J., Woodward, M., 2005. A global forecasting model of political instability. Paper Presented at the Annual Meeting of the American Political Science Association, Washington, D.C., USA, 1-4 September 2005. Available from: <http:// globalpolicy.gmu.edu/pitf/pitfp5.htm> (accessed June 2006).

Goodwin, J., 2001. No Other Way Out - States and Revolutionary Movements, 1945-1991. Cambridge University Press, New York.

Gordenker, L., 1986. Early warning of disastrous population movement. International Migration Review 20, $170-189$.

Gordenker, L., 1992. Early warning: conceptual and practical issues. In: Rupesinghe, K., Kuroda, M. (Eds.), Early Warning and Conflict Resolution. St. Martin's, New York, pp. 1-14.

Greig, J.M., 2005. Stepping into the fray: when do mediators mediate. American Journal of Political Science 49, $249-266$.

Greig. J.M., Rost, N., 2005. Which tool gets used? A multidimensional analysis of conflict management within civil wars. Presented at the Annual Meeting of the Midwest Political Science Association, Chicago, Illinois, April 7-10.

Gurr, T.R., Moore, W.H., 1997. Ethnopolitical rebellion: a cross-sectional analysis of the 1980 s with risk assessments for the 1990s. American Journal of Political Science 41, 1079-1103.

Hadenius, A., Teorell, J., 2007. Authoritarian Regimes Data Set, Version 2.0. Available from: <www.svet.lu.se/Dynamic/personal_page/ Personal homepage lasso?-token.kod=TE > (accessed july 2008)

Harff, B., 1998. Early warning of humanitarian crises: sequential models and the role of accelerators. In: Davies, J.L., Gurr, T.R. (Eds.), Preventive Measures Building Risk Assessment and Crisis Early Warning Systems. Rowman \& Littlefield, Lanham, pp. 70-78.

Harff, B., Gurr, T.R., 1998. Systematic early warning of humanitarian emergencies. Journal of Peace Research 35, 551-579.

\footnotetext{
${ }^{9}$ We tested for this possibility by replacing the GDP and Polity2 variable with dummies that are coded ' 1 ' when the data on these variables is missing for a country-year but found no significant relationship. Still, this issue deserves further investigation.
} 
Harff, B., 2003. No lessons learned from the holocaust? Assessing risks of genocide and political mass murder since 1955. American Political Science Review 97, 57-73. Genocide and Politicide Data. Available from: <http://globalpolicy.gmu.edu/genocide> (accessed July 2008).

Hegre, H., Sambanis, N., 2006. Sensitivity analysis of empirical results on civil war onset. Journal of Conflict Resolution 50, 508-535.

Hegre, H., Ellingsen. T., Gates, S., Gleditsch. N.P., 2001. Towards a democratic civil peace? democracy, political change, and civil war 1816-1992. American Political Science Review 95, 33-48.

Heston, A. Summers, R., Ater, B., 2006. Penn World Table Version 6.2. Center for International Comparisons of Production, Income and Prices at the University of Pennsylvania.

Human Security Centre, 2005. Human Security Report 2005. Oxford University Press, Oxford/New York.

Human Security Centre, 2006. Human Security Brief 2006. Available from: <http://www.hsrgroup.org/images/stories/HSBrief2006/contents/ finalversion.pdf> (accessed June 2009).

King, G., Langche, Z, 2001. Improving forecasts of state failure. World Politics 53, 623-658.

Krain. M. 1997. State-sponsored mass murder: the onset and severity of genocides and politicides. Journal of Conflict Resolution 43, 331-360.

Lacina, B., Gleditsch, N.P., 2005. Monitoring trends in global combat: a new dataset of battle deaths. European Journal of Population $21,145-166$.

Marshall. M.G.. Jaggers, K., 2007. Polity IV Project: Political Regime Characteristics and Transitions, 1800-2006. Version 2006. Center for Systemic Peace. Available from: <www.cidcm.und.edu/inscr/polity/index htm> (accessed October 2004).

Mason. T.D., Krane, D., 1989. The political economy of death squads: toward a theory of the impact of state-sanctioned terror. International Studies Quarterly 33, 175-198.

Poe, S.C., Tate, C.N., 1994. Repression of human rights to personal integrity in the 1980s: a global analysis. American Political Science Review 88, $853-872$.

Poe, S.C., Tate, C.N., Camp Keith, L. 1999. Repression of the human right to personal integrity revisited: a global cross-national study covering the years 1976-1993. International Studies Quarterly 43, 291-313.

Poe, S.C., Rost. N.. Carey, S.C., 2006. Assessing risk and opportunity in conflict studies: a human rights analysis. Journal of Conflict Resolution 50, 484-507. Rashid, A, 2008. Descent into Chaos - How the War Against Islamic Extremism is being Lost in Pakistan, Afghanistan and Central Asia. Penguin, London. Rasler, K., 1986. War, accommodation, and violence in the United States, 1890-1970. American Political Science Review 80, 921-945.

Riedmiller, M., Braun, H., 1993. A direct adaptive method for faster backpropagation learning: the RPROP algorithm. Proceedings of the IEEE Internationa Conference on Neural Networks (ICNN) 16, 586-591.

Sambanis, N, 2004. What is civil war? Conceptual and empirical complexities of an operational definition. Joumal of Conflict Resolution 48, 814-858.

Schneider, G. Wiesehomeier, N., 2008. Rules that matter: political institutions and the diversity-conflict nexus. Journal of Peace Research 45, 183-203.

Schrodt, P. 2004[1995]. Patterns, Rules and Learning: Computational Models of International Behavior, second edition of unpublished manuscript. Available from: <http://web.ku.edu/keds/papers.dir/Schrodt.PRL2.0.pdf> (accessed 22.03.09).

Singer, J.D., Wallace, M.D. 1979. To Augur Well - Early Warning Indicators in World Politics. Sage Publications, Beverly Hills.

Thoms, O.N.T., Ron, ]., 2007. Do Human Rights Violations Cause Internal Conflict? Human Rights Quarterly 29, $674-705$.

UNDP. United Nations Development Programme (2008): Human Development Report 2007/2008. Palgrave Macmillan, New York.

Ward, M.D., Bakke, K., 2005. Predicting civil conflicts: on the utility of empirical research. Paper Presented at the Conference on Disaggregating the Study of Civil War and Transnational Violence, University of California Institute of Global Conflict and Cooperation, San Diego, CA, USA. 7-8 March 2005.

Ward, M.D., Siverson, R.M., Cao, X., 2007. Disputes, democracies, and dependencies: a reexamination of the Kantian peace. American Journal of Political Science 51, 583-601.

World Bank, 2008. World Development Indicators. World Bank, Washington, DC. Available from: <www.worldbank.org/data> (accessed July 2008).

Zanger, S.C., 2000. A global analysis of the effect of political regime changes on life integrity violations, 1977-1993. Joumal of Peace Research 37, 213-233. 